\author{
Please refer to the definitive version of this article when citing: \\ Dwyer L., Seetaram N., Forsyth P. and B. King (2014). "Is the Migration-Tourism Relationship only \\ about VFR?" Annals of Tourism Research, 46(3), 130-143.
}

\title{
Is the Migration-Tourism Relationship only about VFR?
}

\begin{abstract}
This paper contributes to the literature on the linkages between tourism and migration. Though it is widely recognised that the two phenomena are closely linked, and that migration may induce VFR (visiting friends and relatives) tourism, there has been little econometric evaluation of the relationship. The present analysis draws upon Australian data to identify a strong quantitative link between migration and VFR tourism. It also demonstrates a strong link between migration and other forms of tourism. Indeed the latter are almost equally as strong as the links between migration and VFR tourism. This unexpected finding has implications for policymakers and for conceptualising the migration-tourism relationship.
\end{abstract}

Keywords: Migration, Visiting Friends and Relatives, Australia, Tourism Demand.

\section{INTRODUCTION}

In a world of increasing mobilities, it is not surprising that migrants will travel between their new and old countries. Indeed this phenomenon continues to expand in both scale and scope. It is evident that permanent migration and tourism are interconnected and that the relationship operates in both directions (Dwyer, Burnley, Forsyth and Murphy 1993; Williams and Hall, 2002). It is therefore understandable that considerable analysis has been undertaken on the links between migration and the form of tourism most associated with migration, namely visiting friends and relatives (VFR). As well as exploring how VFR tourism is affected by migration, this paper also investigates the effects on non- VFR tourism. The evidence suggests that the effect on non -VFR tourism is almost as strong as on VFR tourism.

It is unsurprising that the migration and VFR tourism phenomena are connected. It is commonplace for residents in the former homeland of migrants who have departed to settle in another country, to maintain contact. Within diasporic communities, many migrants maintain strong emotional and social attachments with their previous homeland (Philpott, 1968; 1973; Rubenstein, 1979; Nguyen, and King, 2002) as well as familial and friendship ties (Gmelch, 1992; Basch et al, 1994).When settlers depart from their home country to establish new lives, 
tourism may be stimulated through visits by friends and relatives (VFR) in both directions. Where there is a larger quantum of permanent migrants in a destination, there will be a larger pool of friends and relatives that are resident in source countries and who have a reason and/or incentive for making visits. Permanent migrants who travel to their country of origin to visit friends and relatives may engage in 'promotion' of their new homeland, whether explicitly or implicitly, thereby stimulating short term inbound visitation.

An increased quantum of migrants in a destination country increases the capacity of accommodation that is available in the homes of residents and which may be accessed by friends and family who are visiting from abroad, thereby reducing trip costs. The presence of permanent migrants enriches cultural life and provides the destination country with greater tourist-related interest and diversity (eg. 'Chinatowns', business and social precincts frequented by residents with Chinese ethnicity often appeal to tourists). Even where international visitors have no friends and/or relatives of their own in the destination, awareness that their compatriots have chosen to settle and contribute to the relevant community may enhance their disposition to visit. Permanent migrants who retain or forge business links with their country of origin may stimulate international trade and associated business travel. A proportion of permanent migrants will boost outbound tourism by making return visits to friends and relative in their previous country of residence, including for special occasions such as weddings and funerals (Paci, 1994; Seaton and Tagg, 1995; Yuan et al, 1995; Feng and Page, 2000). Finally, there may be a boost for permanent migration to countries that have attracted inward migration as visitation for tourism purposes increases, (King, 1994; King and Gamage, 1994).

Tourism researchers have widely acknowledged the connection between more and less permanent forms of migration (King 1994; Williams and Hall 2000,2002; Oigenblick and Kirschenbaum 2002). Prospective migrants sometimes set off for their destination intending to relocate permanently, whereas others undertake shorter stays, but then extend their stay, sometimes permanently. Employees who are relocated overseas for a defined period may fall into the "temporary migrant" category. Some permanent migrants make a conscious or unconscious decision to cut ties with their country of origin on arrival. Most maintain contact with family members and this is increasingly the case with the accessibility that is provided by various forms of social media. Concerted efforts to re-assemble families in destination settings ("family reunion") is a component of the migration program in many countries. 
However assembling family members for shorter periods is more correctly viewed as a subset of tourism and specifically of VFR tourism. Since migration is a global phenomenon involving the dispersal of with those who share common geographical or ethnic backgrounds to diverse locations, it is likely that their chosen destinations will attract subsequent temporary or permanent migrant flows.

The Australian context is particularly relevant to the present research because immigration has played a prominent role in national development in the post War period and Australia continues to receive large scale migration relative to its population. Irrespective of political persuasion, Australian governments have had a longstanding interest in so-called 'multiculturalism', a concept which recognizes migrant contributions to national development and celebrates cultural diversity. Following the establishment of the Federation of Australia in 1901 there was a specific policy espousing a preference for British or European immigrants (this was subsequently described as the "White Australia Policy").Over the course of the 1970s and 1980s, as Australia became more strongly integrated into the AsiaPacific region, the strategy was progressively amended to accommodate migrants from Asian sources. Australia's migrant intake has accelerated and diversified over the two decades of economic growth since the recessionary conditions of the early 1990s. The migration program expanded over the course of the 1990s and annual intakes reached an all-time high during the early years of the present century. Given the importance of tourism to the national economy also (Tourism Research Australia 2010), it is unsurprising that the inter-relationship between the two phenomena is an area of research interest. Howver, while there has been limited research on migration and its impact on VFR tourism, the relationship between migration and other tourism motivations has been a particular area of neglect. The connections between other forms of tourism and migration are less obvious than with VFR with the possible exception of educational tourism.

Several Australian studies have explored the migration-tourism interrelationship since the early investigations of migration-induced tourism by Smith and Toms (1978) and by Hollander (1982). These researchers used regression analysis to show that the proportion of the Australian population who have been born in a particular overseas country is a significant determinant of demand for both inbound and outbound leisure tourism. The market segments that the respective authors used in their studies, namely business and leisure tourism, each 
included a VFR dimension.Recently, Seetaram and Dwyer (2009) and Seetaram (2012a, 2012 b) used a more sophisticated panel data technique to show that immigration influences total inbound tourism to and outbound tourism from Australia. The estimated short term and long term elasticities for international arrivals were 0.03 and 0.09 respectively, while the equivalent short term and long term elasticities for outbound departures were 0.189 and 0.63.These elasticities are high enough to conclude that the level of migration stocks in Australia is an important determinant of inbound tourism and particularly for outbound tourism. More recently, Leitao and Shahbaz (2012) examined the relationship between immigration and Portuguese tourism demand for the period 1995-2008, using a dynamic panel data approach. The regression results show that the main determinants of Portuguese VFR tourism include changes in immigration levels.

Though they provided valuable insights, the above studies did not provide a separate analysis of VFR and non- VFR flows. Jackson (1990) was the first researcher to give explicit recognition to the importance of VFR in migration induced tourism. Jackson concluded that the volume of total VFR tourism groups in Australia, both inward and outward, is closely and significantly associated with the size of different migrant stocks and the duration of their residence. Dwyer, Burnley, Forsyth and Murphy (1993) subsequently undertook a study of tourism-migration links in Australia and established a clear relationship between migration and VFR inbound and outbound tourism flows. They also concluded that migration has a greater impact on outbound VFR tourism than on inbound VFR tourism. The respective migration elasticities were estimated to be 0.5 for international VFR arrivals and 0.6 for international VFR departures (a 10\% increase in the stock of migrants in Australia was shown to increase inbound VFR tourism by 5\% and outbound VFR tourism by 6\%). The study also provided preliminary evidence of a maturation effect, with evidence of a diminution in travel activity once settlers are better established in their country of adoption. The 1993 study also examined the effect of migration on non- VFR inbound and outbound tourism and concluded that migration has effects on non- VFR tourism, albeit on a lesser scale than with VFR tourism. However the study has some limitations because of short period of consideration and lack of econometric analytical rigour.

While the studies of Jackson (1990), and Dwyer et al (1993) indicate that the major tourism market most impacted by migration is VFR, most researchers, including have ignored 
possible differences between the effects of migration on VFR and non-VFR flows. The present study aims to remedy this neglect by exploring the key migration related determinants of tourism flows, using the most up-to-date Australia-related data, and sophisticated methodologies. The paper adheres to the following structure. First, VFR tourism is assessed in terms of both size and value. This exposes some false assumptions that have contributed to the neglect of this market segment by tourism researchers. Second, the paper presents Australian migration flows and population statistics along with comparable inbound and outbound tourism flows, segmented by purpose of travel and including VFR though not confined to this dimension. This section provides basic data to estimate the responsiveness of tourism flows to migration and quantifies the non- VFR and VFR components. Third, the paper draws on recent visitor and population and migration data to provide a quantitative estimation of the significance of tourism-migration interrelationships in Australia by proposing econometric estimates of the impacts of migration on tourism flows. A tourism demand model is proposed with a view to determining the effects of immigration on international tourist arrivals to and departures from Australia, distinguishing VFR and non VFR tourism. The influence of migration on VFR tourism, non-VFR and total tourism is examined with reference to the inbound and outbound markets. Perhaps surprisingly nonVFR tourism, both inbound and outbound, is found to be highly responsive to migrant numbers. The final section discusses the results and proposes opportunities for further research.

\section{ARE THE DIMENSIONS OF VFR TOURISM MEASURED ACCURATELY?}

For the purposes of the present study, the researchers adopt Backer's view that VFR tourism is a form of travel 'involving a visit whereby either (or both) the purpose of the trip or the type of accommodation involves visiting friends and/or relatives' (Backer, 2007, p.369). Although some researchers have undertaken detailed research on this market (Braunlich and Nadkarni, 1995; Yaman, 1996; Seaton \& Palmer, 1997; Backer 2010, 2011; Shania and Uriely 2012, Shani 2013), it has been neglected relative to other purposes of travel. Compounding the challenge of building a clear international picture, most national tourism statistics do not identify VFR as a discrete category. Until about a decade ago, relatively few National Tourism Organisations included VFR as a category within their official statistics (Paci, 1994; Jackson, 2003). Even in the case of UNWTO statistics, VFR forms part of a complex composite purpose of travel category which includes VFR, health, religion and other. 
For the year 2010 the category VFR, religion, health, and other' category was estimated to comprise 27 per cent of international tourism flows (UNWTO 2011).

Despite its neglect relative to other tourist motivations, researchers have begun to acknowledge that the importance of VFR tourism to destinations is greater than was previously acknowledged and that the neglect is based on several misconceptions (Morrison, 1995; Seaton and Tagg, 1995; Yaman, 1996). A preoccupation with total visitor numbers can lead analysts to underestimate the significance of VFR, which is characterised by an extended average length of stay and associated expenditures (Jackson, 2003; Backer, 2010).The economic significance of migration-induced VFR tourism may also be underestimated when the additional expenditures by residents who are hosting their friends and relatives are omitted. Whilst the costs borne by hosts who are supporting visiting friends and family and not classifiable as tourism expenditures in the true sense, they may be an important source of the revenues associated with migration-related VFR tourists (Forsyth, Dwyer, Seetaram and King, 2012). When completing their visitor entry cards, VFR travellers may classify themselves as on holiday, thereby exacerbating the tendency to understate official VFR numbers (Jackson, 2003). Misperceptions may also have arisen about the contribution of VFR because formal tourist facilities may be bypassed more than is the case with other market segments. VFRs may also be less responsive to long established practices of tourism development and destination marketing, thereby lessening interest amongst tourism industry stakeholders. The inaccuracies of some of the assumptions that have led to a neglect of VFR have recently been exposed (Morrison, Hsieh and O'Leary, 1995; Seaton and Palmer 1997; Backer, 2007, 2010, 2011). While VFR travel is one of the largest and most significant forms of tourism, it 'remains well-known but not known well' (Backer, 2011, p. 2).

Recent studies have provided insights into the value of VFR tourism and its associated spending patterns, seasonal, factors and the socio-demographic profiles of VFR tourists (Braunlich and Nadkarni, 1995; Boyne, 2001; Hu and Morrison, 2002; Backer 2011; Shani 2012). While research on VFR tourism has progressed, VFR- migration linkages has been neglected. The present study is timely in view of changes to Australia's migration profile, the relative neglect of VFRs and questions about whether the influence of migration extends to non VFR tourism. 


\section{MIGRATION AND TOURISM FLOW DATA FOR AUSTRALIA}

The main information sources informing migration-tourism linkages are the respective statistics regarding tourism and migration flows. The following section outlines migration and tourism statistical trends to Australia over the period 1980-2009. Covering an extended period of three decades, these data provide raw material for the statistical analyses of migration-tourism interrelationships.

\section{Migration Flows}

The major sources of settlement in 1990/91 were the UK (with 20,746 - 22\%), Hong Kong (14.3\%) and Vietnam (14\%). In 2005-06 the UK remained Australia's largest source with 23,290 migrants $(23.8 \%$ ), followed by New Zealand (which rose dramatically from $7.9 \%$ to $19.5 \%$ including a spike to $32 \%$ in $2001 / 02)$, India (11.6\% up from $5.4 \%$ ) and China (10.8\%, up from 3.4\%). Collectively these four sources accounted for two thirds of all migration into Australia in 2005-06.

\section{Inbound Tourism}

Over the extended period covered by the present investigation (1990 to 2009), overseas visitor arrivals to Australia increased from 2.2 million to 5.6 million. The proportion of arrivals attributable to different purposes of visit have varied over the two decades, with an increase in holidaymakers during the first decade followed by relative decline.Holiday travel grew rapidly through the 1980s and by 1991 it accounted for a majority of arrivals with VFR declining to a $20 \%$ share. Tourism for holiday purposes had declined by 2001 , to about half of all visitation with VFR accounting for a 19.4\% share. By 2009 the holidaymaking share had again shrunk to less than half, with the share of VFRs increasing to $24.7 \%$. The 'other' category (including students) remained substantial, accounting for an increased share over 1991. Australia's success as an emerging education destination offers a partial explanation for the buoyancy of the 'other' category, with about 500,000 international students enrolled in Australia-basedcourses at secondary and postsecondary level. Recent research has shown that education is closely linked with VFR and that most international tertiary students hosted family during the course of their enrolment, notably to attend graduations (Davidson et al, 2011). Despite a fall in 2009, migrant numbers have been strengthened by recent policy changes that have enhanced the prospects of securing work within Australia for international 
students after graduation which has also enhanced their prospects of gaining permanent residency

\section{Outbound Tourism}

In comparing the final decade of the twentieth century with the first decade of the twenty first, the overall share of holiday travel in total outbound travel from Australia was similar in 2009 (53.3\%) to 1991 (54.8\%). The VFR share, which was $21.6 \%$ in 1991 , had grown to $25.5 \%$ by 2009. As VFR increased its share, business travel experienced a relative decline. The respective share for business travel dropped between 1991 and 2009 from $14.5 \%$ to $10.9 \%$.

A model of tourism demand is proposed to determine the effects of immigration on international tourist arrivals to and departures from Australia with consideration to both VFR and Non VFR tourism. The variable 'estimated Australian residents born overseas', which acts as a proxy for the stock of migrants in Australia, is only obtainable from the census data. The model incorporates the most recently published census data (2006) to prepare estimates for a cross section of 29 countries. The models have also been estimated for another census year - 1991 -because this inclusion provides an opportunity to compare the respective elasticities on an inter-temporal basis and demonstrate how the relative importance of various tourism determinants has changed over 15 years. The initial estimates in the model make use of total tourist numbers, irrespective of purpose of visit. The next stage involves re-estimates firstly using VFR tourist numbers and then non-VFR tourist numbers as the dependent variables. The inputs have been deemed to be both valid and reliable because they consist of official Australian Bureau of Statistics data.

The model is as follows:

$$
\mathrm{LV}_{\mathrm{ijk}}=\alpha_{1} \mathrm{LY}_{\mathrm{i}}+\alpha_{2} \mathrm{LP}_{\mathrm{ij}}+\alpha_{3} \mathrm{LAF}_{\mathrm{ij}}+\alpha_{4} \mathrm{LM}_{\mathrm{i} / \mathrm{j}}+\alpha_{5} \mathrm{LPeak}_{\mathrm{i} / \mathrm{j}}+\alpha_{6} \mathrm{LPOP}_{\mathrm{i}}+\varepsilon_{\mathrm{i}}
$$

Where:

$\mathbf{i}$ is the tourism generating country and $\mathbf{j}$ is the destination.

$\mathrm{k}$ is the purpose of travel and takes the values of 1,2 and 3. $(1=$ Total; $2=$ VFR; and $3=$ NonVFR)

$\alpha$ `s and $\lambda$ are the parameters to be estimated. 
$\mathrm{LV}_{\mathrm{ijk}}$ represents the number of short-term travel flows from country $\mathbf{i}$ to destination $\mathbf{j}$.

$\mathrm{LY}_{\mathrm{i}}$ represents the income in country $\mathbf{i}$. The gross domestic product per capita in US dollar equivalence at purchasing power parity (GDP per capita in US\$ PPP) of the home country is used as a proxy for this variable. $\boldsymbol{\alpha}_{1}$ is expected to be greater than zero, since it is assumed that consumers will treat international holidays as a normal good. Note that in the model of outbound tourism, the variable' income' is the GDP per capita at the destination. This gives an indication of the economic development and can be used as a proxy for the quality of infrastructure at the destination. It is expected that Australians will be more inclined to travel to destinations with better access to infrastructure.

$\mathrm{LP}_{\mathrm{ij}}$ represents the relative price between origin $\mathrm{i}$ and destination $\mathrm{j}$. According to Song and $\mathrm{Li}$ (2008), the use of real exchange rates is a commonplace proxy for the prices used in tourism demand modeling. However, Smith and Toms (1978), Philips and Hamal (2000) and Seetaram (2012b) have expressed doubts about whether real exchange rates are a good proxy for prices in tourism demand models. Seetaram (2012b) argues that this variable does not capture the price effect of demand accurately, particularly in the modelling of outbound tourism this may occur as a result of strong collinearity between income and exchange rate when the data that is being used is derived from an open economy. On this basis, a different proxy for price is used in the current study. $\mathrm{LP}_{\mathrm{ij}}$ is a competitiveness index which captures the price effect and is constructed using the method developed in Seetaram (2011).

$\mathrm{LAF}_{\mathrm{ij}}$ represents the transportation cost from origin $\mathrm{i}$ to destination $\mathrm{j} . \mathrm{LAF}_{\mathrm{it}}$ is the natural logarithm of the round trip real economy airfares between Sydney and a main airport of the origin/destination, lagged by one year. These data were obtained from the international ABC World Airways Guide (various issues) and Passenger Air Traffic monthly publications (various issues), and adjusted by the CPI prevailing in the home country. This variable represents the cost of travel to and from Australia. $\boldsymbol{\alpha}_{3}$ is expected to be negative given that the higher the travel cost the less will be the demand for travel.

The effect of migration is captured through two variables $\mathrm{LM}_{\mathrm{i} / \mathrm{j}}$ and $\mathrm{LPeak}_{\mathrm{i} / \mathrm{j} .} \mathrm{LM}_{\mathrm{i} / \mathrm{j}}$ represents the estimated resident population of Australia born in origin $\mathbf{i}$ (for model on arrivals) and in destination $\mathbf{j}$ (for model on departures). This variable incorporates the effect of the stock of migrants in Australia. Inputs were obtained from census data published by the ABS. $\boldsymbol{\alpha}_{\mathbf{4}}$ is 
expected to be positive, as the higher the stock of immigrants in Australia the higher will be the number of international trips between Australian and the migrant's country of origin. LPeak $_{\mathrm{i} / \mathrm{j}}$ is the number of years elapsed since the migration occurring from one of the 29 countries reached its peak. This variable captures the effects of migrant length of stay in Australia. (Bureau of Immigration Research, Settler Arrivals Statistical Reports, numerous years and Department of Immigration and Citizenship, Settler's Arrival, various issues).

$\mathrm{LPOP}_{\mathrm{i}}$ is the population level in each of the 29 countries included in the sample. $\boldsymbol{\alpha}_{\mathbf{6}}$ is expected to be positive since, other things equal, the greater is the population of an origin country the greater is its potential pool of outbound tourists. Finally, $\boldsymbol{\varepsilon}_{\mathbf{i}}$ is the idiosyncratic error term.

In this model, the variables are in logarithmic form which implies that the estimated coefficients are the respective demand elasticities. The model was estimated using EViews 7. Since the specified model is linear, estimation is undertaken using the Ordinary Least Square (OLS) technique. The preferred approach produces estimates with optimal properties. Several tests have been performed with a view to verifying the validity of the model and the robustness of the estimates.

All six models pass the F-Test for overall significance. A comparison of the six results shows that the best fit is evident for those VFR models with the highest $\overline{\mathrm{R}}^{2}$. The AIC and Schwarz criteria obtained confirm this result. . The results of a Jarque-Bera (1981) test show that the error terms were normally distributed for all models except for Total 1991.The Breusch and Pagan (1979) and Godfrey(1978) test confirmed that that autocorrelation was not a problem in any of the models. However the Breush and Pagan (1979) test revealed that Total 2006 suffered from heteroscedasticity. These results were confirmed using a White (1980) test. The model was re-estimated using the White (1980) method to obtain heteroscedasticityconsistent standard errors.

\section{Inbound Tourism}

Table 1 presents the elasticities applicable to international arrivals to Australia in 1991 and 2006 for total and VFR related tourism flows. 
Table 1. Demand Elasticities for Short-Term Arrivals to Australia: 1991, 2006

\begin{tabular}{|c|c|c|c|c|c|c|}
\hline & \multicolumn{3}{|c|}{1991} & \multicolumn{3}{|c|}{2006} \\
\hline & $\begin{array}{c}1 \\
\text { Total }\end{array}$ & $\begin{array}{c}2 \\
V R \\
\end{array}$ & $\begin{array}{c}3 \\
\text { Non } V R\end{array}$ & $\begin{array}{c}4 \\
\text { Total } \\
\end{array}$ & $\begin{array}{c}5 \\
V R \\
\end{array}$ & $\begin{array}{c}6 \\
\text { Non } V R\end{array}$ \\
\hline Income & $\begin{array}{l}1.424^{* * *} \\
(5.55) \\
\end{array}$ & $\begin{array}{l}1.058^{* * *} \\
(3.97) \\
\end{array}$ & $\begin{array}{l}1.551^{* * * *} \\
(5.10) \\
\end{array}$ & $\begin{array}{c}0.977^{* * *} \\
(3.90) \\
\end{array}$ & $\begin{array}{c}0.797^{* * *} \\
(4.50) \\
\end{array}$ & $\begin{array}{c}1.009^{* * *} \\
(3.57) \\
\end{array}$ \\
\hline Relative Price & $\begin{array}{l}-0.216^{* * *} \\
(-2.49) \\
\end{array}$ & $\begin{array}{l}-0.134^{* *} \\
(-2.23)\end{array}$ & $\begin{array}{l}-0.295^{* * *} \\
(-2.58) \\
\end{array}$ & $\begin{array}{l}-0.927^{* *} \\
(-2.05) \\
\end{array}$ & $\begin{array}{c}-0.158^{* * *} \\
(-2.50) \\
\end{array}$ & $\begin{array}{l}-1.005^{* *} \\
(-2.01)\end{array}$ \\
\hline $\begin{array}{c}\text { Transportation } \\
\text { cost }\end{array}$ & $\begin{array}{c}-1.481^{* * * *} \\
(-4.01)\end{array}$ & $\begin{array}{c}-0.955^{* * *} \\
(-2.45) \\
\end{array}$ & $\begin{array}{c}-1.683^{* * *} \\
(-4.26) \\
\end{array}$ & $\begin{array}{l}-0.481^{* *} \\
(-2.12)\end{array}$ & $\begin{array}{l}-0.334^{*} \\
(-1.92)\end{array}$ & $\begin{array}{l}-0.506^{*} \\
(-1.86)\end{array}$ \\
\hline Migration number & $\begin{array}{l}0.336 \\
(2.02) \\
\end{array}$ & $\begin{array}{c}0.488^{* * *} \\
(4.64) \\
\end{array}$ & $\begin{array}{l}0.262 \\
(1.23) \\
\end{array}$ & $\begin{array}{c}0.591^{* * *} \\
(6.52) \\
\end{array}$ & $\begin{array}{l}0.658^{* * * *} \\
(9.39) \\
\end{array}$ & $\begin{array}{l}0.564^{* * *} \\
(5.61) \\
\end{array}$ \\
\hline $\begin{array}{l}\text { Migration average } \\
\text { years in Australia }\end{array}$ & $\begin{array}{l}0.066 \\
(0.31) \\
\end{array}$ & $\begin{array}{l}0.194 \\
(1.28)\end{array}$ & $\begin{array}{l}0.005 \\
(0.02)\end{array}$ & $\begin{array}{l}-0.137 \\
(-0.41) \\
\end{array}$ & $\begin{array}{l}-0.015 \\
(-0.07) \\
\end{array}$ & $\begin{array}{l}-0.214 \\
(-0.55)\end{array}$ \\
\hline $\begin{array}{l}\text { Population in } \\
\text { origin countries }\end{array}$ & $\begin{array}{c}0.352^{* * *} \\
(3.09)\end{array}$ & $\begin{array}{c}0.134^{* *} \\
(2.04)\end{array}$ & $\begin{array}{c}0.396^{* * * *} \\
(3.18)\end{array}$ & $\begin{array}{l}0.084 \\
(1.11) \\
\end{array}$ & $\begin{array}{l}0.021 \\
(0.39) \\
\end{array}$ & $\begin{array}{l}0.085 \\
(0.94) \\
\end{array}$ \\
\hline \multicolumn{7}{|c|}{ Diagnostic Testing and Statistics } \\
\hline$\overline{\mathrm{R}}^{2}$ & 0.51 & 0.61 & 0.47 & 0.58 & 0.74 & 0.51 \\
\hline DW & 2.18 & 2.3 & 2.2 & 1.950 & 1.86 & 1.932 \\
\hline \multicolumn{7}{|c|}{ Model Validity } \\
\hline F-Stats $(6,23)$ & $\begin{array}{c}5.84 \\
(\mathrm{P}=0.00)\end{array}$ & $\begin{array}{c}16.95 \\
(\mathrm{P}=0.00)\end{array}$ & $\begin{array}{c}5.54 \\
(\mathrm{P}=0.00)\end{array}$ & $\begin{array}{c}996.69 \\
(\mathrm{P}=0.00)\end{array}$ & $\begin{array}{c}1155.61 \\
(\mathrm{P}=0.00)\end{array}$ & $\begin{array}{c}782.84 \\
(\mathrm{P}=0.00)\end{array}$ \\
\hline AIC & 3.25 & 1.92 & 3.54 & 2.77 & 2.01 & 3.05 \\
\hline Schwarz Criteria & 3.48 & 2.17 & 3.78 & 3.06 & 2.30 & 3.33 \\
\hline \multicolumn{7}{|c|}{ Normality of Error Term } \\
\hline Jarque- Bera & $\begin{array}{c}5.08 \\
(\mathrm{P}=0.08)\end{array}$ & $\begin{array}{c}2.42 \\
(\mathrm{P}=0.30)\end{array}$ & $\begin{array}{c}3.08 \\
(\mathrm{P}=0.21)\end{array}$ & $\begin{array}{c}0.701 \\
(\mathrm{P}=0.70)\end{array}$ & $\begin{array}{c}0.74 \\
(\mathrm{P}=0.69)\end{array}$ & $\begin{array}{c}0.12 \\
(\mathrm{P}=0.94)\end{array}$ \\
\hline \multicolumn{7}{|c|}{ Breusch-Pagan -Godfrey Test for Heteroscedasticity ${ }^{l}$} \\
\hline $\mathrm{F}$-Stats $(5,23)$ & $\begin{array}{c}0.07^{2} \\
(\mathrm{P}=0.76)\end{array}$ & $\begin{array}{c}0.48^{2} \\
(\mathrm{P}=0.43)\end{array}$ & $\begin{array}{c}0.08^{2} \\
((\mathrm{P}=0.09) \\
\end{array}$ & $\begin{array}{c}1.47 \\
(\mathrm{P}=0.23)\end{array}$ & $\begin{array}{c}0.83 \\
(\mathrm{P}=0.51)\end{array}$ & $\begin{array}{c}2.33 \\
(\mathrm{P}=0.67)\end{array}$ \\
\hline \multicolumn{7}{|c|}{ Breusch -Pagan Test for Serial Correlation ${ }^{1}$} \\
\hline $\mathrm{F}$-Stats $(1,23)$ & $\begin{array}{c}0.45 \\
(\mathrm{P}=0.41)\end{array}$ & $\begin{array}{c}0.6 \\
(\mathrm{P}=0.57)\end{array}$ & $\begin{array}{c}0.423 \\
(\mathrm{P}=0.37)\end{array}$ & $\begin{array}{c}0.03 \\
(\mathrm{P}=0.86)\end{array}$ & $\begin{array}{c}0.83 \\
(\mathrm{P}=0.81)\end{array}$ & $\begin{array}{c}0.08 \\
(\mathrm{P}=0.78)\end{array}$ \\
\hline
\end{tabular}

Source - Estimated by authors using Eviews 7. Inbound tourism relates to short-term international visitor arrivals staying less than one year in Australia. (ABS Cat. 3401.0). Unless otherwise specified, values in parentheses are T-Statistics. ***, **, * - significant at the $1 \%, 5 \%$ and $10 \%$ level respectively. ${ }^{I}$ Tests results were doubled checked by running other tests. 1 lag was used for the Breusch -Pagan Test for Serial Correlation. ${ }^{2}$ Test results indicate the presence of heteroscedasticity, therefore the respective models were estimated using the White method. All other regressions were performed using Ordinary Least Square.

The results indicate that migration had become a more important determinant of Australian international tourist arrivals in 2006, than was the case in 1991. A $10 \%$ increase in migration numbers would have generated an increase in total tourism arrivals in 1991 and 2006 of 3.36\% and $5.91 \%$ respectively. In 1991, migration numbers were a greater influence on total tourism arrivals than Australia's relative destination price competitiveness, but less influential than 
was the case with income, transport costs and population in origin countries. In 2006 migrant numbers were more influential than transport cost and population as determinants of inbound tourism. Interestingly, income and transportation costs were more influential determinants of total inbound tourism for the period between 1991 and 2006, whereas relative price levels between Australia and visitor source countries assumed greater importance. Migration was the second placed determinant of VFR arrivals after income in the case of both 1991 and 2006. A $10 \%$ increase in migration would have produced additional VFR flows of $4.88 \%$ and 6.58\% respectively for 1991 and 2006. Relative price levels between Australia and origin countries assumed greater importance for VFR tourists in 2006 over 1991, while the importance of income and transportation costs declined. The reduced importance of income may relate to the fact that VFR tourists in Australia increasingly opt to stay with friends and relatives rather than in commercial accommodation (Backer, 2010).

A novel and interesting finding of this study is that migration numbers had a substantially greater influence on non-VFR tourist arrivals in 2006 than in 1991. A 10\% increase in migration would have increased arrivals by non VFR tourists by $5.64 \%$ in 2006, compared to $2.62 \%$ in 1991. Migration stocks in 2006 had a greater effect on non-VFR flows than was the case with transportation costs. As noted earlier, this may reflect inaccurate statistics- genuine VFR visitors may report reasons other than VFR tourism as their primary motivation. The significance of migration as a driver of non-VFR tourism suggests that, migrants may have formed networks within Australia in the period since 1991 that are stimulating travel for purposes other than VFR. This differing result may reflect changes in the migrant mix over the period since 1991. Most migrants to Australia in the period prior to 1991 were European, whereas an increasing share has now emanated from Asia. In many respects, the link between migration and non VFR tourism is unsurprising. Some non-VFR tourists may be induced to explore countries with which they have only an indirect familiarity because of the presence of a migrant community. However, it is noticeable that, for 2006, the elasticities for total and non-VFR tourism with respect to migration are not much less than are the case for VFR tourism. This issue clearly merits further investigation.

In contrast to the substantial influence of migration numbers on total and VFR tourism arrivals, there was no affect attributable to the length of stay of migrants in Australia. LPEAK was expected to capture the effect of length of stay and was the only insignificant variable at the ten percent level in both years. This remains a limitation of the current study. 


\section{Outbound Tourism}

Table 2 presents the elasticities applicable to international departures from Australia in 1991 and 2006 for total and VFR related departures.

Table 2. Demand Elasticities for Short-Term Departure from Australia: 1991, 2006

\begin{tabular}{|c|c|c|c|c|c|c|}
\hline & \multicolumn{3}{|c|}{1991} & \multicolumn{3}{|c|}{2006} \\
\hline & $\begin{array}{c}7 \\
\text { Total }\end{array}$ & $\begin{array}{c}8 \\
V R\end{array}$ & $\begin{array}{c}9 \\
\text { Non } V R\end{array}$ & $\begin{array}{c}10 \\
\text { Total }\end{array}$ & $\begin{array}{c}11 \\
V R\end{array}$ & $\begin{array}{c}12 \\
\text { Non } V R\end{array}$ \\
\hline Income & $\begin{array}{c}1.190^{* * *} \\
(6.34)\end{array}$ & $\begin{array}{c}0.851^{* * *} \\
(6.25)\end{array}$ & $\begin{array}{l}1.291^{* * *} \\
(5.47)\end{array}$ & $\begin{array}{c}0.800^{* * * *} \\
(2.50) \\
\end{array}$ & $\begin{array}{c}0.590^{* * *} \\
(3.25) \\
\end{array}$ & $\begin{array}{l}1.009^{* * * *} \\
(3.586)\end{array}$ \\
\hline Relative Price & $\begin{array}{c}-0.232^{* *} \\
(2.16) \\
\end{array}$ & $\begin{array}{c}-0.221^{*} \\
(1.93) \\
\end{array}$ & $\begin{array}{c}-0.155^{* *} \\
(2.21) \\
\end{array}$ & $\begin{array}{l}-0.61^{* *} \\
(-2.23)\end{array}$ & $\begin{array}{l}-0.28^{* *} \\
(-2.17)\end{array}$ & $\begin{array}{l}-0.61^{* *} \\
(-2.02) \\
\end{array}$ \\
\hline $\begin{array}{c}\text { Transportation } \\
\text { cost }\end{array}$ & $\begin{array}{c}-1.554^{* * *} \\
(-4.63) \\
\end{array}$ & $\begin{array}{c}-0.856^{* * *} \\
(-4.00) \\
\end{array}$ & $\begin{array}{c}-1.780^{* * *} \\
(-4.76) \\
\end{array}$ & $\begin{array}{c}-0.30 \\
(-0.90) \\
\end{array}$ & $\begin{array}{c}-0.22 \\
(-1.12) \\
\end{array}$ & $\begin{array}{c}-0.37 \\
(-1.02) \\
\end{array}$ \\
\hline $\begin{array}{c}\text { Migration } \\
\text { number }\end{array}$ & $\begin{array}{c}0.476^{* * *} \\
(3.96)\end{array}$ & $\begin{array}{c}0.549^{* * *} \\
(8.26)\end{array}$ & $\begin{array}{l}0.434 \\
(2.97) \\
\end{array}$ & $\begin{array}{l}0.72^{* * * *} \\
(7.14)\end{array}$ & $\begin{array}{l}0.71^{* * *} \\
(8.83)\end{array}$ & $\begin{array}{l}0.69^{* * *} \\
(7.46)\end{array}$ \\
\hline $\begin{array}{c}\text { Migration } \\
\text { average years in } \\
\text { Australia }\end{array}$ & $\begin{array}{l}0.100 \\
(0.54) \\
\end{array}$ & $\begin{array}{c}0.200^{* * *} \\
(2.52)\end{array}$ & $\begin{array}{c}0.067^{* * *} \\
(2.97)\end{array}$ & $\begin{array}{c}0.18 \\
(0.43)\end{array}$ & $\begin{array}{c}0.19 \\
(0.61)\end{array}$ & $\begin{array}{c}0.15 \\
(0.33)\end{array}$ \\
\hline $\begin{array}{c}\text { Population in } \\
\text { origin countries }\end{array}$ & $\begin{array}{l}0.42^{* * *} \\
(3.95) \\
\end{array}$ & $\begin{array}{c}0.172^{* * *} \\
(3.03) \\
\end{array}$ & $\begin{array}{c}0.487^{* * *} \\
(4.10)\end{array}$ & $\begin{array}{l}0.09^{*} \\
(1.86) \\
\end{array}$ & $\begin{array}{l}0.11^{*} \\
(1.82) \\
\end{array}$ & $\begin{array}{l}0.19^{*} \\
(1.86) \\
\end{array}$ \\
\hline \multicolumn{7}{|c|}{ Diagnostic Testing and Statistics } \\
\hline$\overline{\mathrm{R}}^{2}$ & 0.47 & 0.74 & 0.43 & 0.35 & 0.28 & 0.28 \\
\hline DW & 2.02 & 2.00 & 2.05 & 2.22 & 1.84 & 2.28 \\
\hline \multicolumn{7}{|c|}{ Model Validity } \\
\hline F-Stats & $\begin{array}{c}6.25 \\
(\mathrm{P}=0.00)\end{array}$ & $\begin{array}{c}14.49 \\
(\mathrm{P}=0.00)\end{array}$ & $\begin{array}{c}5.15 \\
(\mathrm{P}=0.00)\end{array}$ & $\begin{array}{l}1182.72 \\
(\mathrm{P}=0.00)\end{array}$ & $\begin{array}{l}1794.76 \\
(\mathrm{P}=0.00)\end{array}$ & $\begin{array}{c}892.94 \\
(\mathrm{P}=0.00)\end{array}$ \\
\hline AIC & 2.82 & 1.72 & 3.13 & 2.31 & 2.58 & 3.39 \\
\hline Schwarz Criteria & 3.10 & 2.00 & 3.42 & 2.54 & 2.72 & 3.53 \\
\hline \multicolumn{7}{|c|}{ Normality of Error Term } \\
\hline Jarque- Bera & $\begin{array}{c}2.55 \\
(\mathrm{P}=0.28)\end{array}$ & $\begin{array}{c}2.14 \\
(\mathrm{P}=0.34)\end{array}$ & $\begin{array}{c}1.00 \\
(\mathrm{P}=0.61)\end{array}$ & $\begin{array}{c}2.04 \\
(\mathrm{P}=0.04)\end{array}$ & $\begin{array}{c}0.81 \\
(\mathrm{P}=0.67)\end{array}$ & $\begin{array}{c}2.12 \\
(\mathrm{P}=0.35)\end{array}$ \\
\hline \multicolumn{7}{|c|}{ Breusch-Pagan-Godfrey Test for Heteroscedasticity* } \\
\hline F-Stats & $\begin{array}{c}0.003^{2} \\
(\mathrm{P}=0.01)\end{array}$ & $\begin{array}{c}0.83 \\
(\mathrm{P}=0.78)\end{array}$ & $\begin{array}{c}0.004^{2} \\
(\mathrm{P}=0.13)\end{array}$ & $\begin{array}{c}4.40^{2} \\
(\mathrm{P}=0.01)\end{array}$ & $\begin{array}{c}0.013 \\
(\mathrm{P}=0.91)\end{array}$ & $\begin{array}{c}4.74^{2} \\
(\mathrm{P}=0.00)\end{array}$ \\
\hline \multicolumn{7}{|c|}{ Breusch-Pagan Test for Serial Correlation* } \\
\hline F -Stats & $\begin{array}{c}0.59 \\
(\mathrm{P}=0.54)\end{array}$ & $\begin{array}{c}0.74 \\
(\mathrm{P}=0.70)\end{array}$ & $\begin{array}{c}0.49 \\
(\mathrm{P}=0.42)\end{array}$ & $\begin{array}{c}0.57 \\
(\mathrm{P}=0.46)\end{array}$ & $\begin{array}{c}1.23 \\
(\mathrm{P}=0.32)\end{array}$ & $\begin{array}{c}0.67 \\
(0.42)\end{array}$ \\
\hline
\end{tabular}

Source - Estimated by authors using Eviews 7. Outbound tourism relates to short term departures by residents who travel overseas for less than one year (ABS Cat. 3401.0). Unless otherwise specified, values in parentheses are T-Statistics. ***, **, * - significant at the $1 \%, 5 \%$ and $10 \%$ level respectively. ${ }^{1}$ Tests results were doubled checked by running other tests. ${ }^{2}$ Test results indicate the presence of heteroscedasticity, therefore the respective models were estimated using the White method. All other regressions were performed using Ordinary Least Square. 
The results of the F-Test indicate that the coefficients of the explanatory variables are not simultaneously equal to zero. The $\overline{\mathrm{R}}^{2}$, AIC and Schwarz criteria confirm that the model with VFR fitted the data best for 1991, whereas total departures fitted the data best in 2006. The Jarque Bera statistics show that the errors are normally distributed and the results of the Breusch-Godfrey test show that autocorrelation is not a problem in either model. The Breusch Pagan (1979) test however, revealed that the models Total1991 and non-VFR 1991 and 2006 were subject to heteroscedasticity. In order to address this problem, the models were reestimated using the White (1980) method to obtain heteroscedasticity-consistent standard errors.

The results that are reported in Table 2 indicate that immigration had become a more important determinant of total international tourist departures from Australia in 2006 relative to 1991 . In the latter year, migration numbers were less important than transportation costs and income as a determinant of outbound tourism but more important than relative prices or the population of other countries. A $10 \%$ increase in the stock of migrants in Australia would have generated an increase in total outbound tourism in 1991 and 2006 of $4.76 \%$ and $7.20 \%$ respectively. Though migrant numbers were less influential than income by 2006, they were nevertheless more influential than income, relative prices and population as determinants of total outbound tourism. Interestingly, the influence of income and transportation costs as determinants of total inbound tourism declined between 1991 and 2006 while migration numbers and price relativities between Australia and visitor source countries assumed greater importance.

In 1991, migration was the third most important determinant of VFR related departures, behind income and transport costs. However, by 2006, migration had become the most important determinant, even exceeding income as an influence. In 1991 a 10\% increase in migration would have produced an additional 5.49\% in VFR outbound flows, though by 2006 the comparable figure had dropped to $7.10 \%$. The relative price level between Australia and origin countries assumed greater importance for VFR travellers in 2006 over 1991, while income, transportation costs and population declined in importance. Whilst outbound VFR tourists have become more responsive to changes in migration numbers, they have become less sensitive to changes in income, transportation costs and relative prices. As was the case 
with overall international arrivals, VFR tourists were least responsive to changes in the cost of international travel. It may be the case that as permanent settlers have progressively arrived from the 29 listed countries, there has been increasing interest in the origin countries as prospective destinations for short-term trips. Additional destination information may have become available through word of mouth communication and social media.

As was the case for inbound tourism, non-VFR outbound travel was found to be highly responsive to migration numbers. A $10 \%$ increase in migration to Australia would have generated an increase of $4.34 \%$ and $6.90 \%$ in non-VFR outbound tourism in 1991 and 2006 respectively. In 1991 and particularly in 2006, the response of non VFR tourism to migration was only marginally less than was the case for VFR tourism. The results indicate that the influence of migration on outbound tourism extends beyond VFR motivated tourism. In contrast to the important influence of migration numbers on total and VFR tourism arrivals, the length of stay in Australia had no effect. As is the case with the model of inbound tourism, LPEAK is the only insignificant variable at the $10 \%$ level in either year. It is concluded that this variable was failing to capture the effect of length of stay of the migrant, indicative of a limitation of the current study. Future research on the migration-tourism link should address this shortcoming.

\section{RESULTS, IMPLICATIONS AND CONCLUSIONS}

As an important global market, VFR tourism is closely associated with the history and development of international migration patterns. This study has confirmed that migration is an important determinant of VFR tourism and that the relationship has progressively grown. A $10 \%$ increase in migration would have produced additional inbound VFR flows of $4.88 \%$ and $6.58 \%$ respectively for 1991 and 2006, and additional outbound VFR flows of $5.49 \%$ and $7.10 \%$. respectively. The strength of the migration and non-VFR tourism relationship is a striking result from the econometric analysis. A 10\% increase in migration would have increased arrivals by non VFR tourists by $5.64 \%$ in 2006 , compared to $2.62 \%$ in 1991 , and additional outbound flows of $4.34 \%$ and $6.90 \%$ in non-VFR outbound tourism in thses two years. Given that Australia is a major receiver of immigrants, the results also offer the prospect of informing more accurate forecasts of inbound tourism to Australia. This investigation has suggested that the impacts on VFR tourism should not be the sole focus 
when examining the impact of migration on tourism since all tourism motivations are evidently impacted by migration. The association between migration and tourist numbers is particularly evident in the case of outbound tourism. Whilst the growth of migrant related tourism is well established, the drivers and dynamics of the phenomenon are less well understood. Evolving migration patterns and changes to the determinant factors of tourism pose a continuous challenge to those who are investigating the various linkages. Whilst the existence of migration and tourism relationships is clear, their comparative patterns and strengths have not been studied consistently over time. This has made it difficult to track and explain the fluctuating trends. The findings have provided a stronger context for understanding the motivations associated with tourism and migration by exploring country of origin influences on migrant travel behaviour. The present findings should be of interest to policy makers in the tourism and migration fields, to peak industry bodies and to stakeholders such as airlines and tour operators. The study has indicated that it is appropriate for tourism stakeholders to consider migration numbers alongside other determinants of Australia's outbound flows such as income, aviation costs and exchange rate changes which have dominated recent discussions. By implication, changing migration patterns into Australia will create an ongoing pattern of changes to the various tourism market segments.

To gain greater insights into the effects of migration on both VFR and non-VFR tourism it is necessary to have a better understanding of social networks, cultural traits, ethnic origins and ties. This requirement has exacerbated the challenge of tracking and explaining fluctuating trends. Differences may also be evident between the experiences and behaviours of the various migrant groups which have settled during different periods. To date, there has been little empirical investigation of whether the current relationships connecting migration and tourism resemble those which were applicable to earlier waves of arrivals from Europe. The elasticity findings highlighted in this paper have gone some way towards explaining the influence of economic variables on tourism flows by providing the key migration related determinants of tourism flows, together with qualitative and quantitative estimates of their significance.

Accurate forecasting is at the heart of effective tourism planning and decision making since policy makers, planners and managers must attempt to match supply with future demand. The 
results of the present study can provide important inputs into another neglected area of research, namely determining the economic impacts of migration induced tourism. The estimated elasticities can inform projected changes in tourism numbers that may result from future changes in the stock and flows of migrants into Australia. Given the potential to attach expenditure data to visitor flows for particular inbound and outbound markets, economic modelling can be used to estimate the economy-wide effects on gross domestic product, value added and employment (Forsyth et al 2012).Further research is needed to develop a detailed understanding of the significance of both VFR and non VFR tourism and their underlying motivations. A comprehensive exploration of the influence of country of origin on migrant travel behaviours should provide a stronger context for understanding the motivations associated with inbound tourism and migration. Comparative studies of countries with significant migrant intakes are needed to validate the findings of this study, in particular the strong link that has been identified between migration numbers and non VFR tourism. The extent to which the links between migration and tourism are equally strong in other settings is as yet untested. Given that many countries have large migrant intakes the results of this investigation have prospective implications for destination managers worldwide.

\section{References}

ABC World Airways Guide.Various issues.ABC World Airways Guide Monthly ABC World Airways Guide (Red Book). Beds: Read Travel.

Australian Bureau of Statistics [ABS] various issues. Overseas Arrivals and Departures, Category 3401.0. Retrieved from: http://www.abs.gov.au/ausstats/abs@.nsf/mf/3401.0/

Australian Bureau of Statistics [ABS] (2011). Australian National Accounts Tourism Satellite Account 2010-11, (Cat. No. 5249.0), December, Canberra, http://www.abs.gov.au/

Backer, E. (2007) 'VFR Travel: An Examination of the expenditures of VFR travellers and their hosts',Current Issues in Tourism, 10 (4), 366-377.

Backer, E. (2010) 'Opportunities for commercial accommodation in VFR',International Journal of Tourism Research, 12(4), 334-354

Backer E. (2011)' VFR travel: It IS underestimated',Tourism Management, 33, (5), pp. 74-79. 
Basch, L., Glick Schiller, N. \& Szanton Blanc, C. (1994)National Unbound: Transnational Project and the Deterritorialised National-State, New York: Gordon and Breach.

Boyne, S. (2001) 'Hosts, friends and relatives in rural Scotland: VFR tourism market relationships explored', in L. Roberts, \& D. Hall (Eds.), Rural tourism and recreation:Principles to practice. Wallingford: Cabi Publishing.

Braunlich, C., \& Nadkarni, N. (1995) 'The importance of the VFR market to the hotel industry',The Journal of Tourism Studies, 6(1), 38-47.

Davidson, M, Wilkins, H, King, B, Hobson, P, Craig-Smith, S. \& Gardner, S, (2011). The Travel Behaviours of International Students in Australia. In: Gross, Michael J (Editor). CAUTHE 2011 National Conference: Tourism: Creating a Brilliant Blend. Adelaide, S. A.: University of South Australia. School of Management, 2011: 1021-1024. Available from: http://search.informit.com.au/documentSummary;dn=912942040915126;res=IELBUS

Department of Immigration and Citizenship (2008) The People of Australia, Statistics from the 2006 Census, Commonwealth of Australia, Canberra.

Department of Immigration and Citizenship (2010). Commonwealth of Australia, Canberra Settler's Arrivals, available from http://www.immi.gov.au/media/statistics/statisticalinfo/oad/settlers/setdatb.htm

Dwyer, L., Burnley, I., Forsyth, P. \& Murphy, P. (1993). Tourism-Immigration Interrelationships. Canberra: Bureau of Tourism Research.

Feng, K. \& Page, S. (2000). An exploratory study of the tourism, migration-immigration nexus: Travel experience of Chinese residents in New Zealand. Current Issues in Tourism, 3(3), 246-281.

Forsyth, P., L. Dwyer, N. Seetaram, B. King (2012) "Measuring the Economic Impact of Migration- Induced Tourism” Tourism Analysis, 17, (5), pp 559-571

Gmelch, G. (1992). Double Passage: The Lives of Caribbean Migrants Abroad and Back Home, Ann Arbor, Michigan: University of Michigan Press.

Hollander, G. (1982) 'Determinants of demand for travel to and from Australia', Bureau of Industry Economics, Working Paper No. 26. Canberra, Australia.

Hu, B., and Morrison, A. M. (2002) 'Tripography: can destination use patterns enhance understanding of the VFR market? Journal of Vacation Marketing, 8(3), 201-220.

Jackson, R. (1990) ' VFR tourism: Is it underestimated?'Journal of Tourism Studies 1 (2): 10-17 Reprinted in Special Issue Journal of Tourism Studies, 14(1), 17-24 (2003).

King, B.E.M. (1994) 'What is ethnic tourism? An Australian perspective' Tourism Management 15 (3), 173-6.

King, B.E.M. and Gamage, M.A. (1994)'Measuring the value of the ethnic connection: Expatriate travellers from Australia to Sri Lanka'Journal of Travel Research 33 (2), 46-50. 
Lehto, X. Y., Morrison, A. M., \& O'Leary, J. T. (2001) 'Does the visiting friends and relatives' typology make a difference? A study of the international VFR market to the United States'. Journal of Travel Research, 40(2), 201-212.

Leitao N.C and M.Shahbaz (2012) "Migration and Tourism Demand" Theoretical and Applied Economics Volume XIX (2012), No. 2(567), pp. 39-48

Morrison, A. M. (1995) 'The VFR market: desperately seeking respect',Journal of Tourism Studies, 6 (1), 2-5.

Morrison, A. M., Hsieh, S., \& O'Leary, J. (1995) 'Segmenting the visiting friends and relatives market by holiday activity participation' The Journal of Tourism Studies, 6(1), 4863.

Nguyen, T.H. \& King, B.E.M. (2002) 'Migrant communities and tourism consumption: the case of the Vietnamese in Australia', in C.M. Hall and A. Williams (eds.). Tourism and Migration: New Relationships between Production and Consumption, Dordrecht: Kluwer Academic Publishers.

Oigenblick, L. and A. Kirschenbaum (2002), "Tourism and Immigration: Comparing Alternative Approaches," Annals of Tourism Research, 29, 1086-1100.

Paci, E. (1994) ' The major international VFR markets',EIU Travel and Tourism Analyst, 6 (August), 36-50.

Passenger Airtariff Various issues Passenger Airtariff Worldwide Fare book. Middlesex: Pegasus House.

Philips, B., and Hamal, K. (2000, 'Modelling Australian outbound travel demand', paper presented at the Australian Tourism and Hospitality Research Conference, Mt. Buller, Australia.

Philpott, S.B. (1968) Remittance obligation, social networks and choice among Montserratian migrants in Britain. Man (N.S.), 3 (3), 465-476.

Philpott, S.B. (1973) 'West Indian Migration: The Montserrat Case', London School of Economics Monographs in Anthropology, No. 47, London: Athone Press.

Rubenstein, H. (1979) 'The return ideology in West Indian Migration', University of Manitoba Paper in Anthropology, 20 (1), 21-38.

Seaton, A.V. and Tagg, S.J. (1995) 'Disaggregating friends and relatives in VFR tourism research', The Northern Ireland evidence 1991-1993. Journal of Tourism Studies 6 (1), 6-18.

Seetaram, N. (2011)“Competitiveness Index Versus Real Exchange Rate As The Proxy For Price In Models Of International Outbound Tourism" Second Conference of the International Association for Tourism Economics, Bournemouth University, $4^{\text {th }}$ to $7^{\text {th }}$ of July, UK.

Seetaram, N. (2012a). "Immigration and Tourism Demand: Empirical Evidence from Australia" Tourism Management, 33(6) pp. 1535-1543. 
Seetaram, N. (2012b) "Estimating Demand Elasticities for Australia's International Outbound Tourism”, Tourism Economics, 18(5). pp.999-1015

Seetaram, N. and L. Dwyer (2009) "Immigration and Tourism Demand in Australia: A Panel Data Approach'ANATOLIA: An International Journal of Tourism and Hospitality Research,20 (1), 212-222.

Shani A. (2013) 'The VFR experience: 'home' away from home?', Current Issues in Tourism, 16:1, 1-15, DOI: 10.1080/13683500.2011.643859

Shani A.(2012) 'VFR Tourism: The Host Experience'Annals of Tourism Research, Vol. 39, No. 1, pp. 421-440, 2012

Smith, A.B. and Toms, J.N. (1978) Factors Affecting Demand for International Travel to and from Australia. Occasional Paper 11, Bureau of Transport, Canberra. Australia.

Song, H., and Li, G. (2008) 'Tourism demand modelling and forecasting a review of recent research', Tourism Management, 29 (2), 203-220.

Tourism Research Australia (2010).State of the Industry 2010, Australian Government,Department of Resources, Energy and Tourism, Tourism Research Australia, Canberra.

UNWTO (2011) Tourism Highlights www.UNWTO.org/facts, Accessed August 10, 2012

Williams, A.M. and C. M. Hall (2000) "Tourism and Migration: New Relationship between Production and Consumption," Tourism Geographies, 2, 5-27.

Williams, A. and Hall, M. (2002). Tourism, migration, circulation and mobility: The contingencies of times and place. in C.M. Hall and A. Williams (eds). Tourism and Migration: New Relationships between Production and Consumption, Dordrecht: Kluwer Academic Publishers.

White, Halbert (1980) 'A heteroscedasticity-Consistent Covariance Matrix Estimator and a Direct Test for Heteroscedasticity’,Econometrica48 (4), 817-838.

Yaman, H. (1996). VFR tourism: issues and implications. In Proceedings from the conference held at Victoria University of Technology. Victoria: Victoria University of Technology.

Yuan, T.F., Fridgen, J.D., Hsieh, S. \& O’Leary, J.T. (1995)' Visiting friends and relatives travel market: The Dutch Case', Journal of Tourism Studies, 6 (1), 19-26. 